
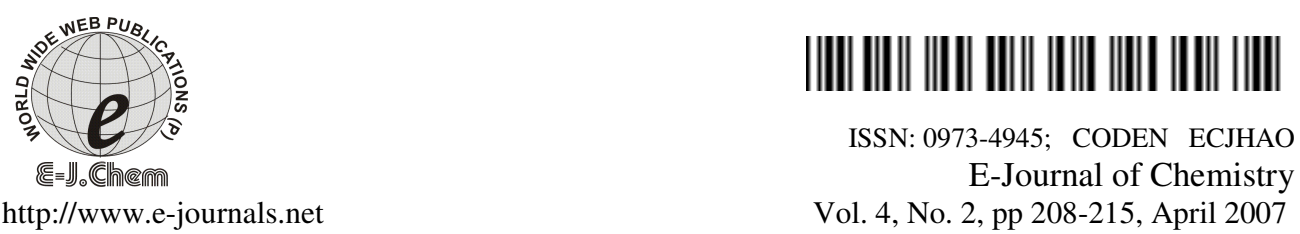

\title{
Screening of Nutritional Parameters for the Production of Protease from Aspergillus Oryzae
}

\author{
G. SRINUBABU*, N. LOKESWARI and K. JAYARAJU \\ Center for Biotechnology, \\ Department of Chemical Engineering, \\ Andhra University, Visakhapatnam, India-530003. \\ Email: srinubabuau6@gmail.com
}

Received 2 July 2006; Accepted 3 August 2006

\begin{abstract}
Production of protease enzyme by fungus Aspergillus oryzae was investigated. The proteolytic activity was observed when the fungus was grown in the medium containing glucose, malt extract, yeast extract, peptone, $\mathrm{K}_{2} \mathrm{HPO}_{4}, \mathrm{MgSO}_{4}$ and $\mathrm{FeSO}_{4}$. The present paper describes the screening of media components and fermentation conditions in shake flask. The organism utilized carbon sources glucose, fructose, sucrose, lactose, dextrin and starch among them glucose was found to be the best carbon source, for nitrogen sources various inorganic and organic media components were investigated among them peptone is found to be the best nitrogen source. $1 \%$ cottonseed followed by $2 \%$ Soya bean meal was found to be the best inducer. With optimized media two-fold increase in the protease production. The fungus growth depends on the concentration of carbon, nitrogen and salt solution, where as the enzyme production was also influenced by the culture time, $\mathrm{pH}$ and interaction between these two variables.
\end{abstract}

Keywords: Protease, Aspergillus oryzae, screening, carbon and nitrogen sources

\section{Introduction}

Protease, a hydrolytic enzyme shares $60 \%$ of total worldwide sale of industrial enzymes ${ }^{1}$. Protease has a long history of application in food, detergent and leather industries and is an important tool in studying the structure of protein and peptides. As is well known microbial proteases are derived from a wide variety of yeasts, molds and bacteria. A large proportion of commercially available proteases are currently derived from bacillus strains. Although potential use of fungal proteases is being increasingly realized ${ }^{2}$ fungal proteases offer a 
distinct advantage over bacterial enzymes in terms of ease of down stream processing. Thirty to forty percent of the production cost of industrial enzymes is estimated to be the cost of the growth medium ${ }^{3}$. Extracellular proteases are important for the hydrolysis of proteins in cell-free environments and enable the cell to absorb and utilize hydrolytic products ${ }^{4}$. At the same time, these extracellular proteases have also been commercially exploited to assist protein degradation in various industrial processes ${ }^{5,6}$. It is important to screen the media components and fermentation conditions for cost-efficient enzyme production; proteases are generally produced by submerged fermentation. In this paper Aspergillus oryzae was investigated for screening of medium components and culture conditions for protease production.

\section{Experimental}

\section{Microorganism and culture conditions}

Aspergillus oryzae 637 was obtained from National Culture of Industrial Microorganisms Pune, India. The organism was maintained on potato-dextrose agar slants at $4{ }^{\circ} \mathrm{C}$. Spores were inoculated into the PDA plate by streaking method from the slant preserved in $4{ }^{\circ} \mathrm{C}$ refrigerator. Spores were scraped from the plate surface by adding distilled water with $0.85 \% \mathrm{NaCl}$ and $0.01 \%$ Tween 80 to the growth agar plate which have been cultivated for 3 days. The concentration of the spore was maintained at level of $10^{8}$ cells per mL. This solution was kept in $4{ }^{\circ} \mathrm{C}$ refrigerator and used as the inoculums into $50 \mathrm{~mL}$ medium. To study the biosynthesis of protease by the isolate Aspergillus oryzae different growth media reported earlier by different workers for protease production were tried Table 1 . The composition of different types of protease production media reported literature was shown in Table.1 the medium PMm was considered as the control of basal medium which contained malt extract-1, glucose-6, yeast extract-1, petone- $2, \mathrm{~K}_{2} \mathrm{HPO}_{4}-0.5, \mathrm{MgSO}_{4} .7 \mathrm{H}_{2} \mathrm{O}-0.5, \mathrm{FeSO}_{4} .7 \mathrm{H}_{2} \mathrm{O}-0.01$. The $\mathrm{pH}$ of the all the media was adjusted by the addition of $1.0 \% \mathrm{~N} \mathrm{Na}_{2} \mathrm{CO}_{3}$ or $0.1 \% \mathrm{~N} \mathrm{HCl}$. Fermentation experiments were run with $50 \mathrm{ml}$ each of the above-described medium (was used to initiate the growth) in $250 \mathrm{ml}$ Erlenmeyer flasks. A $5.0 \%$ level of $24 \mathrm{~h}$ inoculums raised in the basal medium was used to initiate the growth. The inoculated flasks kept on rotary shaker $(140 \mathrm{rpm})$ at $30{ }^{\circ} \mathrm{C}$ for 3 days. One $\mathrm{ml}$ quantities of each sample were withdrawn at every $12 \mathrm{~h}$ from the flasks for protease assay.

Table 1. Protease production in various media

\begin{tabular}{|c|c|c|c|c|}
\hline & Composition of medium (g/100 mL) & $\begin{array}{c}\text { Final } \\
\mathrm{pH}\end{array}$ & $(\mathrm{U} / \mathrm{mL})$ & $\begin{array}{l}\text { Ref } \\
\text { No. }\end{array}$ \\
\hline $\mathrm{PM}_{1}$ & $\begin{array}{l}\text { Glucose-0.2, casein 0.05,peptone } 0.05 \text {, yeast extract } 0.05 \\
\mathrm{KH}_{2} \mathrm{PO} 4-1, \mathrm{MgSO}_{4}-0.5, \mathrm{FeSO}_{4} .7 \mathrm{H}_{2} \mathrm{O}-0.01\end{array}$ & 8.4 & 150 & 7 \\
\hline $\mathrm{PM}_{2}$ & Maltose 1.0, Yeast extract- $0.04, \mathrm{~K}_{2} \mathrm{HPO}_{4}-0.5$, NaCl-0.2 & 8.5 & 196 & 8 \\
\hline $\mathrm{PM}_{3}$ & $\begin{array}{l}\text { Yeast extract- } 1, \mathrm{CaCl}_{2}-0.01 \mathrm{~K}_{2} \mathrm{HPO}_{4}-0.02, \mathrm{MgSO}_{4}-0.05 \\
\mathrm{NaCl}-0.01, \mathrm{~K}_{2} \mathrm{HPO}_{4}-0.5\end{array}$ & 8.6 & 164 & 9 \\
\hline $\mathrm{PM}_{4}$ & $\begin{array}{l}\text { Soybean meal-2, casein- } 1 \text {, corn starch- } 0.5, \mathrm{NH}_{4} \mathrm{Cl}-0.05 \text {, } \\
\mathrm{NaCl}-0.05, \mathrm{KH}_{2} \mathrm{PO}_{4}-0.04, \mathrm{~K}_{2} \mathrm{HPO}_{4}-0.03, \mathrm{MgSO}_{4}-0.02 \text {, } \\
\text { Yeast extract- } 0.01 \text { and } \mathrm{Na}_{2} \mathrm{CO}_{3}-0.6\end{array}$ & 9.6 & 192 & 10 \\
\hline PMm & $\begin{array}{l}\text { Malt Extract-1, Glucose }-6 \text {, yeast extract-1, petone-2, } \\
\mathrm{K}_{2} \mathrm{HPO}_{4}-0.5, \mathrm{MgSO}_{4^{-}}-0.5, \mathrm{FeSO}_{4} \cdot 7 \mathrm{H}_{2} \mathrm{O}-0.01\end{array}$ & 8.3 & 332 & \\
\hline
\end{tabular}




\section{Determination of alkaline protease activity}

Protease activity was determined by a modified procedure based on the method ${ }^{11,12}$ of using $2 \%$ casein in $0.2 \mathrm{M}$ carbonate buffer with $\mathrm{pH} 10$ as a substrate. Casein solution $(0.5 \mathrm{~mL})$ with an equal volume of suitable diluted enzyme solution was incubated at $40{ }^{\circ} \mathrm{C}$. After 10 minutes the reaction was terminated by the addition of $1 \mathrm{~mL}$ of $10 \%$ trichloroacetic acid. The mixture was centrifuged and supernatant was taken, to this $5 \mathrm{~mL}$ of $0.44 \mathrm{M} \mathrm{Na}_{2} \mathrm{CO}_{3}$ and $1 \mathrm{~mL}$ of two fold diluted Folin Ciocalteau reagents were added. After 30 minutes the color developed was read at $660 \mathrm{~nm}$ against reagent blank prepared in the same manner. Tyrosine served as the reference standard. The optical density of these solutions was measured. One unit of enzyme activity was defined as the amount of enzyme that released one $\mu \mathrm{g}$ of tyrosine released per minute.

\section{Results and Discussion}

\section{Protease production in different media}

Production of enzyme was studied initially in media reported in literature for fungal cultures and along with $1 \%$ cottonseed followed by $2 \%$ soybean meal as an inducer PMm broth gave highest activity among the various media tested. Production was poor and very low activities were obtained in yeast extract- $\mathrm{CaCl}_{2}$ or yeast extract-maltose media containing inorganic salts

\section{Inducers}

Various agricultural residues such as groundnut cake $(195 \mathrm{U} / \mathrm{mL})$, mustard seed cake (190 $\mathrm{U} / \mathrm{mL})$, cotton seed cake $(210 \mathrm{U} / \mathrm{mL})$ soybean meal $(215 \mathrm{U} / \mathrm{mL})$ at $2 \%$ concentration were screened as inducers for protease production in PMm broth. Soyabean meal was found to be the best inducer for protease production. In a similar study reported ${ }^{13}$ that $1 \%$ cottonseed protein was the best followed by soyabean meal $(2 \%)$ as inducer for protease production by Aspergilus flavus. We have agreed the results ${ }^{13}$ of Srinivasn and Dhar so $1 \%$ cotton seed followed by $2 \%$ soyabean meal $(240 \mathrm{U} / \mathrm{mL})$ was used as inducer for all subsequent studies.

\section{Age of inoculum}

Inoculum was developed PMm broth by inoculating spores from 0 to 5 days old PDA slant. After 12 or $24 \mathrm{~h}$ of growth, $10 \%$ (v/v) Inoculum was used to inoculate the experimental medium. Table 2 shows that the age of inoculum has no significant effect on alkaline protease production.

Table 2. Effect of inoculum on protease production (48)

\begin{tabular}{ccc}
\hline Inoculum age & Final $\mathrm{pH}$ & Enzyme activity, $(\mathrm{U} / \mathrm{mL})$ \\
\hline 0 & 8.4 & 160 \\
12 & 8.5 & 384 \\
24 & 8.4 & 460 \\
36 & 8.6 & 468 \\
48 & 8.6 & 472 \\
\hline
\end{tabular}

\section{Pre-induced inoculum}

Pre-induced inoculum was developed in PMm medium containing varying concentrations of soyabean meal $(0-2 \%)$. After $24 \mathrm{~h}$ of growth, $10 \%$ vegetative inoculum (v/v) was transferred to production medium viz. PMm $+1 \%$ cotton seed $+2 \%$ SBM. There was no significant increase in activity by using pre-induced inoculum. Hence, all the further experiments were carried out with inoculum grown in PMm broth alone. 


\section{Optimization of concentration of salt solution}

Salt $\left(\mathrm{K}_{2} \mathrm{HPO}_{4}-0.5, \mathrm{MgSO}_{4}-0.5, \mathrm{FeSO}_{4} .7 \mathrm{H}_{2} \mathrm{O}-0.01\right)$ solution concentration from 10 to 70 $\mathrm{mL}$ was studied and the results were tabulated (Table 3), concentration at $50 \mathrm{~mL}$ was chosen as the optimum.

Table 3. Optimization of concentration of salt solution

\begin{tabular}{cc}
\hline $\begin{array}{c}\text { Salt solution } \\
\text { concentration, }(\mathrm{mL})\end{array}$ & $\begin{array}{c}\text { Enzyme activity } \\
(\mathrm{U} / \mathrm{mL})\end{array}$ \\
\hline 10 & 390 \\
20 & 448 \\
30 & 462 \\
40 & 470 \\
50 & 480 \\
60 & 482 \\
70 & 484 \\
\hline
\end{tabular}

\section{Optimization of concentration of constituents of MGYP medium}

The optimum concentrations of the constitutions of MGYP (Malt extract, Glucose, Yeast extract, Peptone) medium, viz, malt extract, glucose, peptone and yeast extract for maximum enzyme production were determined by varying the concentration of one of the components at a time while keeping the concentrations of all other components constant. $1 \%$ cottensed $+2 \%$ SBM was used as an inducer in all cases. Protease production increased steeply with increasing glucose concentration up to $0.6 \%$ (Fig. 1) and further increase up to $1.2 \%$ showed only marginal increase. As can be seen from Fig.2, malt extract concentration from 0.1 to $0.2 \%$ was optimum while increasing the yeast extract concentration beyond $0.2 \%$ did not increase the activity. However, increasing the peptone concentration from 0.1 to 0.5 resulted in slight increase in activity Banerjee et al. reported ${ }^{14}$ significant activities were obtained in media containing yeast extract and malt extract. In our effort to develop a cost effective medium for protease production, costly ingredients such as malt extract and yeast extract were deleted from MGYP and protease production was carried out in GPE medium though activities were lower than in MGYP. Increasing SBM concentration from 1 to $2 \%$ slightly increased activity though MGYP + $1 \%$ cottenseed followed by $2 \%$ SBM was found to be the best medium. Further optimization with respect to cardon source, replacing malt extract with cheaper inorganic or organic nitrogen sources, $\mathrm{pH}$, temperature, etc. was carried out in this medium.

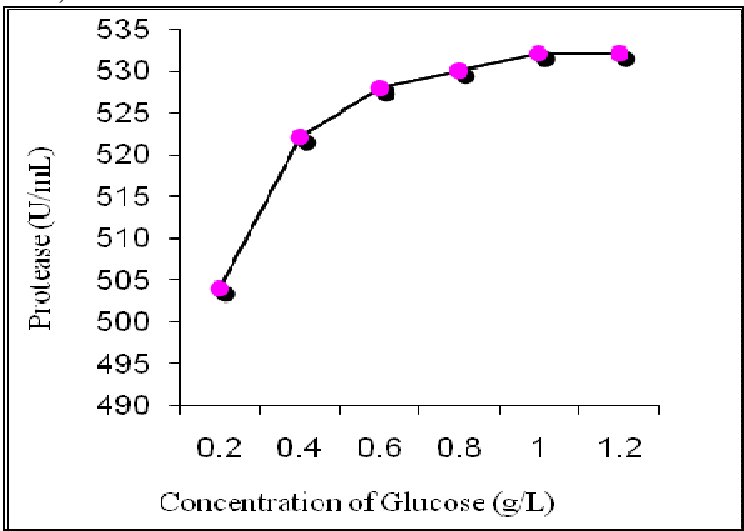

Figure 1. Effect of Carbon concentration on protease production 


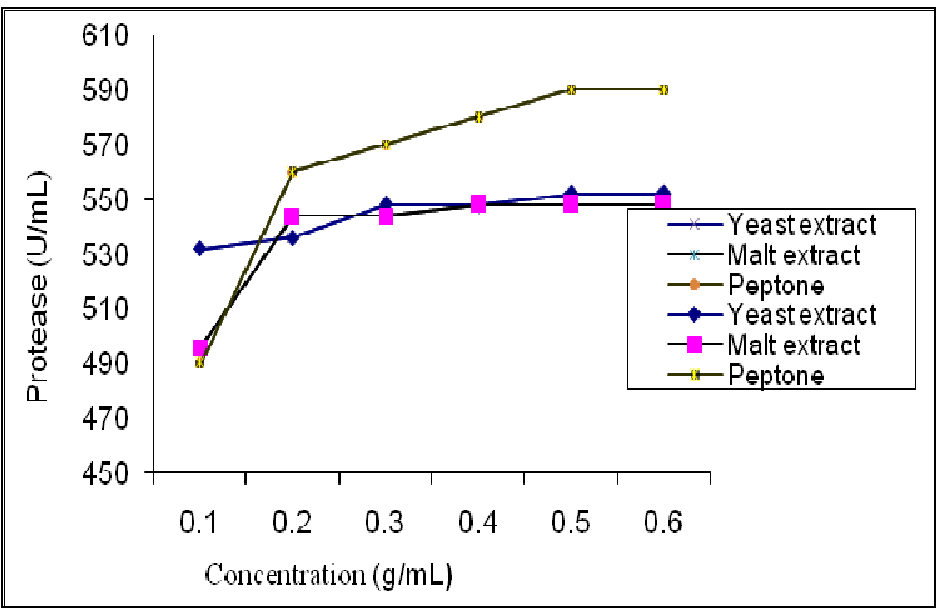

Figure 2. Effect of Nitrogen concentration on protease production

\section{Carbon sources}

Effect of carbon sources $(0.6 \%)$ was studied in YPE+1\% cottonseed followed by $2 \%$ SBM medium where glucose was replaced with sugars or sugar alcohols. Among the various sugars and sugar alcohols tested, glucose was found to be the best followed by fructose (85-90\%) and all other carbon sources gave only 50-60\% activity compared to glucose. Phadatare et al. reported ${ }^{15}$ highest activity with arabinose followed by sucrose while Sutar et al. ${ }^{16}$ found sucrose, glucose and fructose to be equally good to be the best carbon source for protease production by Bacillus brevis $^{14}$ and A. flvaus ${ }^{17}$. Johnvesly and Naik reported ${ }^{18}$ starch; raffinose, arabinose and fructose to be good carbon sources while glucose totally represented protease production. For commercial production, sugars like raffinose, arabinose or maltose will be prohibitive due to their cost and hence starch and glucose will be more suitable as carbon sources.

\section{Nitrogen sources}

Protease production was studied in $1 \%$ glucose as a carbon source and $1 \%$ cotton seed followed by $2 \% \mathrm{SBM}$ as an inducer. Malt extract was replaced with various inorganic (ammonium nitrate, ammonium sulphate, ammonium chloride, diammonium hydrogen phosphate, sodium nitrate and potassium nitrate) or organic (peptone, tryptone, urea, malt extract, casein hydrolysate) nitrogen sources at equivalent nitrogen concentration. Malt extract at $0.2 \%$ was included as control. It was observed that diammonium hydrogen phosphate was found to be the best nitrogen source and all other inorganic N-sources gave 80-90\% protease activity compared to malt extract Table 4(a). Johnvesly and Naik ${ }^{18}$ found that nitrate nitrogen viz. $\mathrm{NaNO}_{3}$ and $\mathrm{KNO}_{3}$ supported protease production while ammonium nitrogen completely inhibited production. Among the organic N-sources, peptone, and casein hydrolysate gave activities similar to yeast extract while activities were slightly lower with, tryptone and urea Table 4(b). Phadatare et $a l^{15}$. reported tryptone followed by peptone and yeast extract to be good organic nitrogen sources while beef extract was poor for protease production by $C$. cornatus. Yeast extract was best followed by casein while beef extract is poor organic nitrogen source for protease production ${ }^{18}$ in termophilic Bacillus sp. JB-99 . Similarly, soyatose and Soya peptone were some of the best organic nitrogen sources for protease production ${ }^{14}$ in B. brevis. 
Table 4. Effect of various carbon sources on proteolytic activity $(\mathrm{U} / \mathrm{mL})$

\begin{tabular}{cccccc}
\hline $\begin{array}{c}\text { Time } \\
\mathrm{h}\end{array}$ & $\begin{array}{c}\text { Fructose } \\
(\mathrm{U} / \mathrm{mL})\end{array}$ & $\begin{array}{c}\text { Lactose } \\
(\mathrm{U} / \mathrm{mL})\end{array}$ & $\begin{array}{c}\text { Glycerol } \\
(\mathrm{U} / \mathrm{mL})\end{array}$ & $\begin{array}{c}\text { Dextrin } \\
(\mathrm{U} / \mathrm{mL})\end{array}$ & $\begin{array}{c}\text { Starch } \\
(\mathrm{U} / \mathrm{mL})\end{array}$ \\
\hline 12 & 260 & 252 & 302 & 252 & 270 \\
24 & 272 & 256 & 314 & 254 & 314 \\
36 & 442 & 360 & 384 & 260 & 390 \\
48 & 496 & 490 & 448 & 290 & 496 \\
60 & 456 & 442 & 442 & 302 & 352 \\
72 & 448 & 388 & 442 & 342 & 440 \\
\hline
\end{tabular}

Table 4 (a). Effect of various nitrogen sources on proteolytic activity (U/mL) (a) Inorganic nitrogen sources

\begin{tabular}{ccccccc}
\hline $\begin{array}{c}\text { Time } \\
\mathrm{h}\end{array}$ & $\begin{array}{c}\text { Sodium } \\
\text { nitrate } \\
(\mathrm{U} / \mathrm{mL})\end{array}$ & $\begin{array}{c}\text { Potassium } \\
\text { nitrate } \\
(\mathrm{U} / \mathrm{mL})\end{array}$ & $\begin{array}{c}\text { Ammonium } \\
\text { chloride } \\
(\mathrm{U} / \mathrm{mL})\end{array}$ & $\begin{array}{c}\text { Ammonium } \\
\text { nitrate } \\
(\mathrm{U} / \mathrm{mL})\end{array}$ & $\begin{array}{c}\text { Ammonium } \\
\text { sulphate } \\
(\mathrm{U} / \mathrm{mL})\end{array}$ & $\begin{array}{c}\text { Diammonium } \\
\text { hydrogen } \\
\text { phosphate } \\
(\mathrm{U} / \mathrm{mL})\end{array}$ \\
\hline 12 & 304 & 296 & 284 & 260 & 270 & 308 \\
24 & 308 & 300 & 284 & 280 & 296 & 316 \\
36 & 316 & 320 & 290 & 284 & 290 & 398 \\
48 & 370 & 374 & 294 & 294 & 320 & 450 \\
60 & 314 & 370 & 290 & 292 & 296 & 450 \\
72 & 320 & 312 & 296 & 292 & 286 & 436 \\
\hline
\end{tabular}

Table 4 (b). Organic nitrogen sources

\begin{tabular}{cccc}
\hline $\begin{array}{c}\text { Time } \\
\mathrm{h}\end{array}$ & $\begin{array}{c}\text { Tryptone } \\
(\mathrm{U} / \mathrm{mL})\end{array}$ & $\begin{array}{c}\text { Casein hydrolysate } \\
(\mathrm{U} / \mathrm{mL})\end{array}$ & $\begin{array}{c}\text { Urea } \\
(\mathrm{U} / \mathrm{mL})\end{array}$ \\
\hline 12 & 300 & 304 & 312 \\
24 & 398 & 324 & 380 \\
36 & 484 & 476 & 454 \\
48 & 490 & 480 & 456 \\
\hline
\end{tabular}

\section{Effect of $p H$}

The effect of initial medium $\mathrm{pH}$ on protease yield was studied in shake flask. Different initial $\mathrm{pH}$ values (7.0-12.0) were used to study their effect on the protease production. The fermentation and assays were carried out in triplicate as the general procedure. It is clear from figure 3(a) that the organism grew well at a wide range of $\mathrm{pH} 7.0$ - 11.0. The maximum cell mass and protease yield were obtained at an initial $\mathrm{pH} 10.0$. So the optimum $\mathrm{pH}$ for protease production was found to be 10.0 it was observed that in alkaline conditions the protease yield was more when compared to acidic conditions.

\section{Effect of incubation temperature}

To study the effect of various temperatures on the growth and alkaline protease production, different temperatures ranges $20,25,30,35$ and $40{ }^{\circ} \mathrm{C}$ were used. The fermentation and assays were carried out in triplicate as described earlier the results are shown in figure 3(b). The results indicate that the organism grew over a wide range. Temperature of $20{ }^{\circ} \mathrm{C}$ and above $35{ }^{\circ} \mathrm{C}$ less growth was observed. The maximum protease production $(456 \mathrm{U} / \mathrm{mL})$ was observed at $30{ }^{\circ} \mathrm{C}$ (Fig.3 b). 


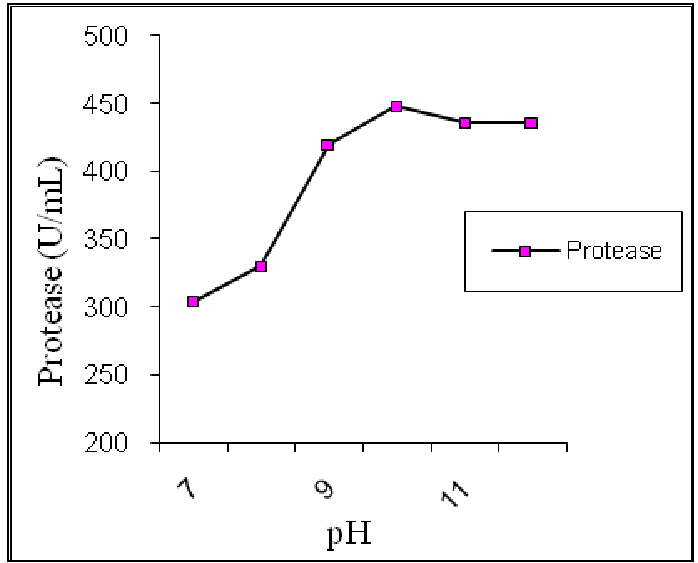

Figure 3(a). Effect of pH on enzyme activity.

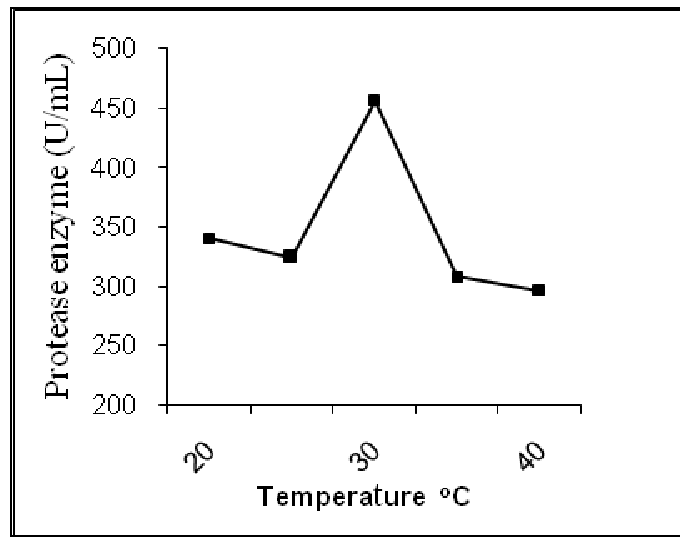

Figure 3 (b). Effect of temperature on enzyme activity

\section{Comparison of PMm media and optimized media}

With optimized media that is malt extract-2, glucose-6, yeast extract-2, petone-3,salt solution $50 \mathrm{~mL}, \mathrm{pH} 10$ and temperature at $30^{\circ} \mathrm{C}$ for $48 \mathrm{~h}$ we have found approximately three fold increase in the protease yield $(950 \mathrm{U} / \mathrm{mL})$.

\section{Conclusions}

In this study, we demonstrated that the culture supernatant of Aspergillus oryzae 637 grown on MGYP medium displayed the proteolytic activity. Among the various inducers tested in the present study $1 \%$ cotton seed followed by $2 \%$ soya been was found to be the best inducer These are inexpensive and readily available making it the substrate of choice for cost effective media formulations. Deletion or reduction of yeast extract and malt extract did not significantly affect the activity; however there is linear increase in activity with increase in peptone concentration up to $0.3 \%$. 


\section{References}

1. Godfrey $\mathrm{T}$ and West S, Introduction to Industrial Enzymology. In: Godfrey T, West S (eds) Industrial enzymology, $2^{\text {nd }}$ (eds.) Macmillan Press, London, 1996, pp 1-8

2. Joo H S, Park G C, Kim K M, Paik S R and Chang C S,.Process Biochem, 2001, 36: $893,900$.

3. Joo H S, Ganesh Kumar C, Park G C, Kim K T and Paik S R, Process Biochem, 2002, 38, 155.

4. Kalisz H M, Adv Biochem Eng Biotechnol, 1988, 36, 1-65.

5. Kumar C G and Takagi H, Biotechnol Adv, 1999, 17, 561-594.

6. Outtrup H and Boyce COL, Microbial Proteinases and Piotechnology. In: Fogarty C T, Kelly K (eds.) Microbial Enzymes and Biotechnology. Elsevier, London,1990, pp 227-254

7. Sandhia G S and Prema P, J. Scientific. Indu. Res. 1998, 57, 629.

8. Tsuchiya.K, Nakamura. Y, Sakashito and Kimura T, Biosci. Biotech. Biochem, 1992, 56, 246-258.

9. Wooly A M, Callaghan J A O and Mahooghin, J. Gen. Microbiol,1983, 129, 981-989.

10. C. Ganesh Kumar, Han-Seung Joo, Yoon-Mo Koo, Seung R. Paik and Chung-Soon Chang, World, J. Microbiol. Biotechnol. 2004, 20 351-357.

11. Varly H, Gowenlock A H and Bell M, Pracical Clinical Biochemistry vol.1 $5^{\text {th }}$ Ed, Willim hein heman book Ltd. London, 1995, 1226,

12. Tsuchida O, Yamagota $\mathrm{Y}$, Ishizuka J, Aria Yamada $\mathrm{J}$ and Takeuchi M, Curr. Microbiol, 1986, 14, 7-12.

13. Srinivas M and Dhar S C, Acta Microbiol Hung, 1990, 15, 23-29.

14. Banerjee U C, Sani R K, Azmi W and Soni R. Process Biochem, 1999, 35, 213-219.

15. Phadatare S U, DespandeV V and srinivas M C, Enzyme.Microbiol.Technol, 1993, 15, 72-76.

16. Sutar, Srinivasan M C and Vartak H G, World J Microbiol Biotechnol, 1992, 8, 254-258.

17. Srinivas M, Dhar S C, Acta Microbiol Hung, 1990, 15, 23-28.

18. Johnvesly B and Naik G R, Process. Biochem, 2001, 37, 213-219. 


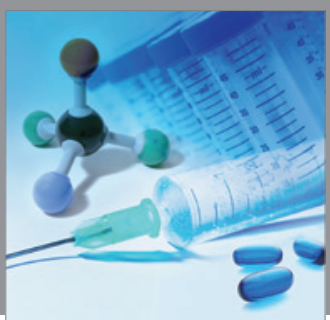

International Journal of

Medicinal Chemistry

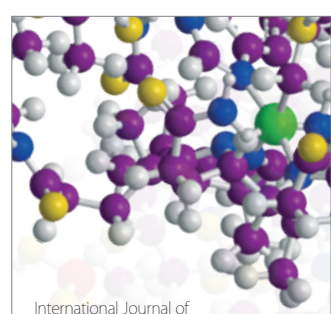

Carbohydrate Chemistry

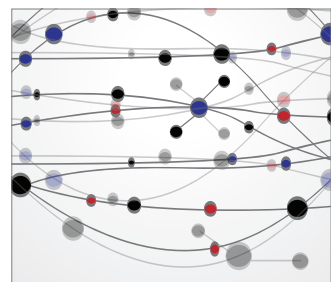

The Scientific World Journal
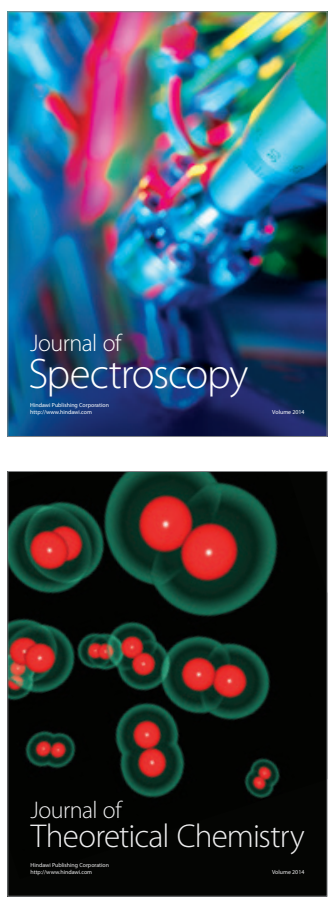
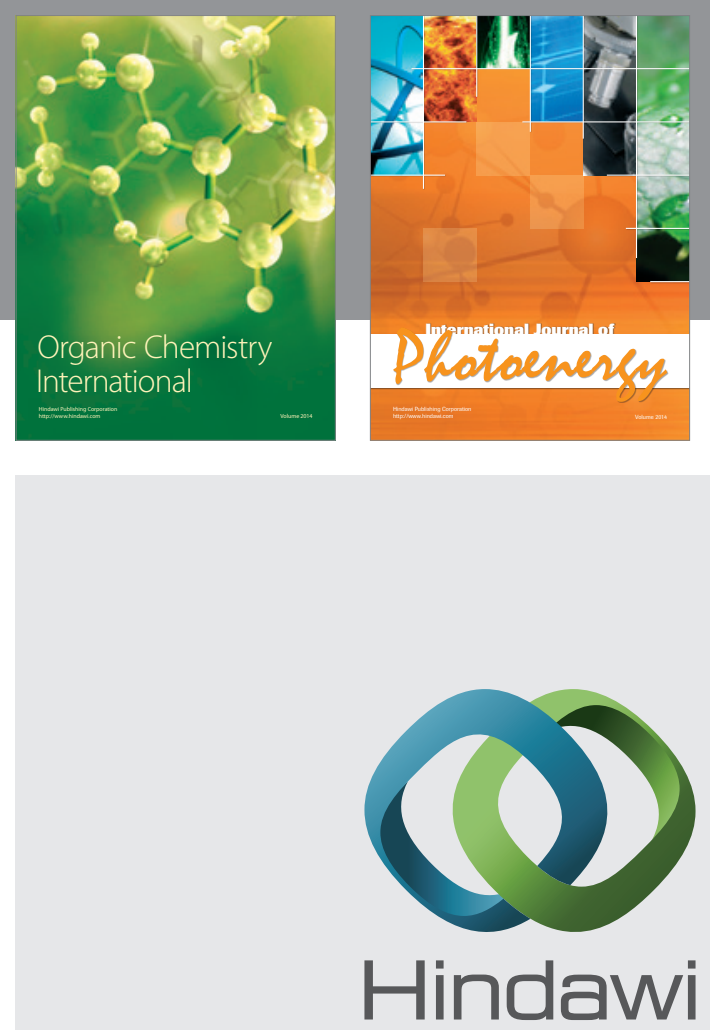

Submit your manuscripts at

http://www.hindawi.com
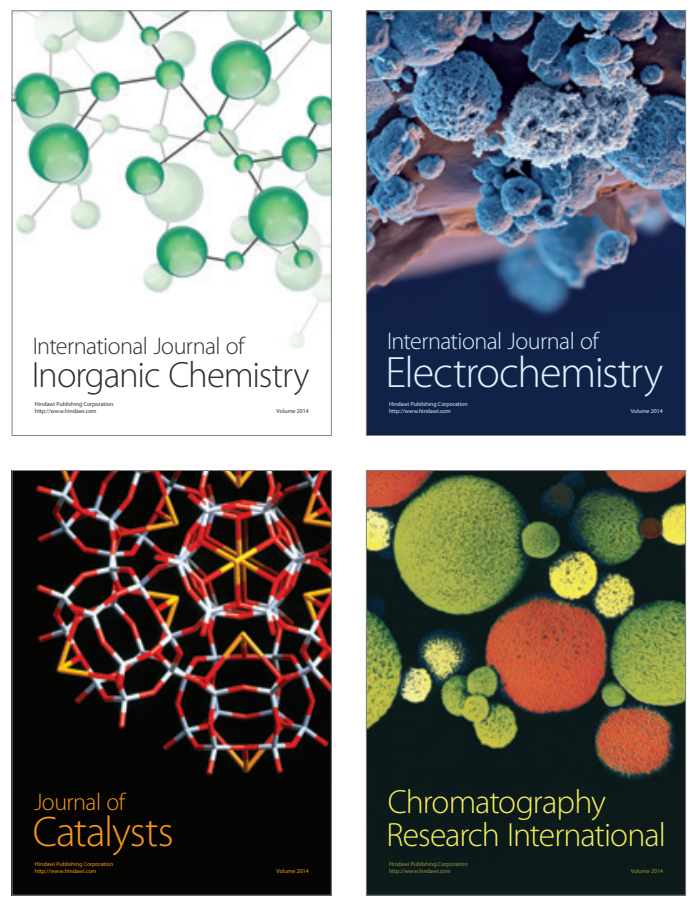
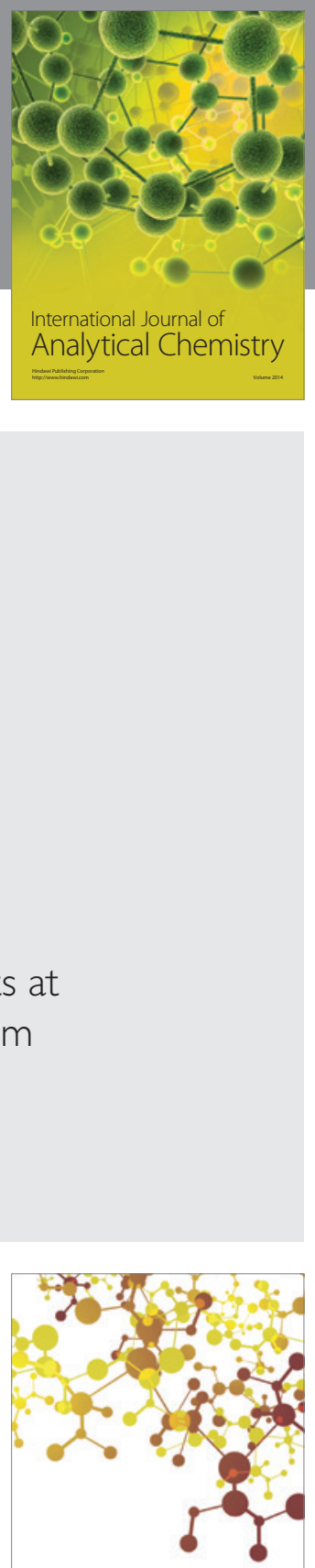

Journal of

Applied Chemistry
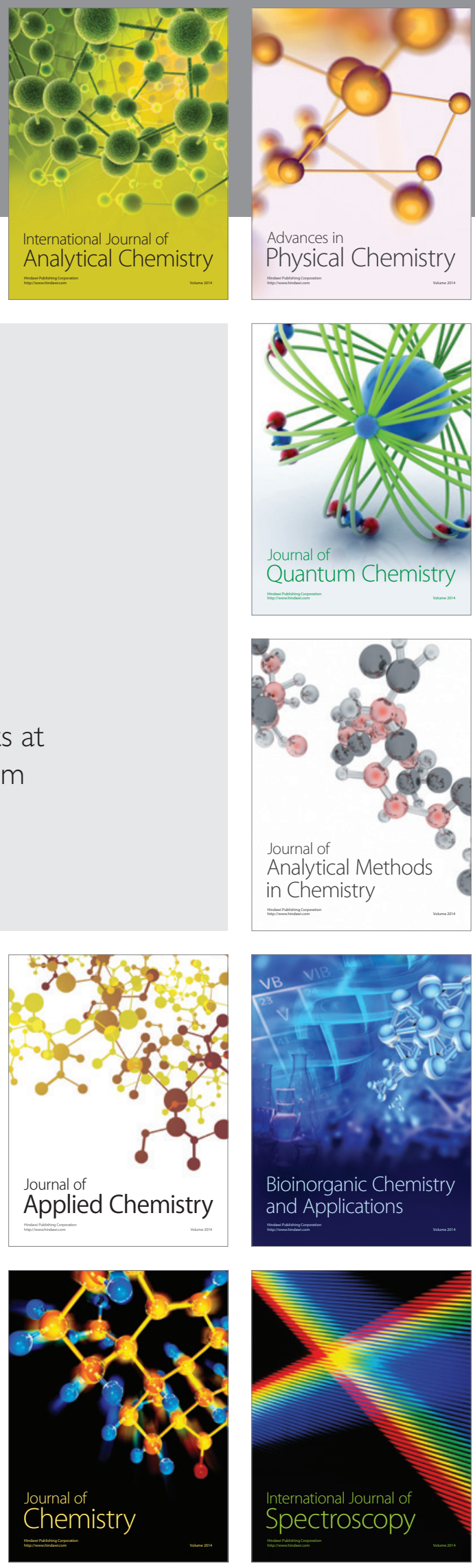